\title{
Leveraging cognitive consistency to nudge conservative climate change beliefs
}

\author{
Hunter Gehlbach \\ gehlbach@ucsb.edu \\ Carly D. Robinson \\ carlyrobinson@g.harvard.edu \\ Christine Calderon Vriesema \\ christine.vriesema@ucsb.edu \\ Gevirtz Graduate School of Education \#3113, University of California, Santa Barbara, Santa \\ Barbara CA 93106-9490
}

\begin{abstract}
People feel motivated to maintain consistency across many domains in life. When it comes to climate change, many find themselves motivated to maintain consistency with others, e.g., by doubting climate change to cohere with friends' and neighbors' beliefs. The resulting climate skepticism has derailed discussions to address the issue collectively in the United States. To counteract these social consistency pressures, we developed a cognitive consistency intervention for climate skeptics. We first demonstrated that most people share substantial faith in a variety of scientific findings, across disciplines ranging from medicine to astronomy. Next, we show that conservative participants who first acknowledge several general contributions of science subsequently report significantly stronger beliefs in climate science (as compared to conservatives who are asked only about their climate science beliefs). These findings provide an encouraging proof-of-concept for how an inclusive climate conversation might be initiated across the political divide.
\end{abstract}




\section{Leveraging cognitive consistency to nudge conservative climate change beliefs}

\section{Introduction}

We like to think that we think for ourselves. Yet, others influence our attitudes, behaviors, and beliefs in ways we may be unaware of. When our beliefs diverge from others in our social network, we often become motivated to address that inconsistency.

This motivation for social consistency has been particularly problematic for addressing climate change. Despite $97 \%$ of climate scientists agreeing that climate change is real, urgent, and human-caused, $28 \%$ of Americans think global warming results from natural temperature fluctuations (Leiserowitz et al., 2018). Such beliefs may persist because believing in climate change might strain social relationships when friends and neighbors believe otherwise (Kahan, 2015). The pervasiveness of climate skepticism has resulted in a dearth of collective conversations to address global warming in the United States.

However, social consistency is not the only influence on our attitudes - incompatible cognitions often motivate people to restore mental equilibrium (e.g., Festinger, 1962). In this pre-registered replication experiment, we embrace a broad theoretical conceptualization of people's motivation to maintain social and cognitive consistency. Focusing on climate change skeptics, we test a cognitive consistency intervention designed to promote greater belief in climate change. As a theoretically-grounded proof-of-concept, this intervention illustrates how cognitive consistency motives might counteract extant consistency pressures from society.

\subsection{The Problem of Social Consistency and Climate Skepticism}

The motivation to maintain social consistency can take many forms, including similarity, social norms, and social proof. For example, to gain acceptance among a group of climate skeptics some might feel pressure to conform by adopting similar views (see Montoya, Horton, \& Kirchner, 2008 for more on similarity). Others, who are uncertain about climate science, might look to respected authorities in their social sphere to adopt socially-appropriate opinions (see Cialdini, 2009 for more on social norms and social proof). Because of the many pathways to maintaining social consistency, we focus our theoretical understanding of climate skepticism 
at the broad level of social consistency rather than targeting a particular psychological mechanism (e.g., similarity or social proof).

However, in targeting interventions for specific populations in particular contexts, researchers need more precision to understand who likely climate skeptics are. Some research suggests that social consistency pressures to disbelieve climate change stem from the political right (Leiserowitz et al., 2018; Oreskes \& Conway, 2010). Other research proposes that people's worldview better explains which social groups will engage in "motivated reasoning" around climate change. Specifically, Kahan et al. (2012) show that those with more egalitarian/communitarian worldviews believe in climate change more than their hierarchical/individualistic counterparts. To accurately target interventions regarding people's climate attitudes, researchers need to accurately identify climate skeptics.

\subsection{The Promise of Cognitive Consistency}

Complementing people's powerful motivations to maintain social consistency, several lines of research show potent effects of cognitive consistency interventions. Like social consistency motivations, cognitive consistency might manifest through different specific psychological mechanisms such as cognitive dissonance (Aronson, 1992; Festinger, 1962) or foot-in-the-door effects (e.g., Cialdini, 2009). Even Piaget's (1977) learning theory can be viewed as relying on cognitive consistency motivations-learners are motivated to change their understanding of the world only when their current schemas appear inconsistent with their observations and thus need to be replaced by new schemas to restore cognitive equilibrium.

In sum, we theorize that climate change skeptics and believers are both motivated to hold attitudes that cohere with the social groups to which they belong (e.g., their political party or those who share their worldview). Creating cognitive inconsistencies for climate skeptics could counteract the social consistency pressures they face in their communities, potentially shifting their beliefs.

\subsection{Intervention and Hypotheses}

To generate cognitive inconsistency among climate skeptics, we drew from recent work showing how surveys can be used as interventions (Gehlbach, Robinson, Finefter-Rosenbluh, 
Benshoof, \& Schneider, 2018). Despite recent evidence that conservative's confidence in science has eroded in recent decades (Gauchat, 2012), we expected that most people find some branches of science credible, even if they doubt others. Combining these two ideas, we leveraged the motivation for cognitive consistency to try to shift the views of climate science skeptics by asking first about their beliefs in science before asking them about climate science.

Based on the potential political and worldview differences in climate beliefs (Kahan et al., 2012; McCright, Dunlap, \& Xiao, 2013) and a preliminary exploratory study, we preregistered the following hypotheses in line with recommended practices (Gehlbach \& Robinson, 2018):

1) Conservative participants experiencing the consistency intervention would report greater belief in climate science than their control counterparts.

2) Across the full sample, the treatment would disproportionately increase beliefs in climate science for participants with less egalitarian perspectives.

\section{Methods}

A preliminary exploratory study tested whether our cognitive consistency intervention could counteract the social pressure many Americans feel to disbelieve climate change. We found that our approach effectively shifted the attitudes of politically conservative participants. This study also indicated that participants' egalitarian beliefs (though not their communitarian beliefs) might be a more powerful moderator than political orientation (Kahan et al., 2012). Thus, we included egalitarianism but omitted communitarianism as measures in our pre-registered study. Appendix A of the supplementary online materials details this exploratory study.

\subsection{Participants}

To obtain sufficient numbers of conservative participants, we sought 750 U.S. participants from Amazon's Mechanical Turk. From the 906 participants who entered the survey, we obtained a final analytic sample of 699 . We present full details of how attrition and exclusions occurred in Appendix B.

The sample was $57 \%$ female $\left(M_{\text {age }}=38.2\right.$ years, $\left.S D=10.9\right)$, and the median participant held a four-year college degree. Participants identified as White (79\%), Black/African American 
(10\%), Asian/Pacific Islander (5\%), and Latinx/Hispanic American (4\%). Politically, 27.5\% of the participants categorized themselves as conservative, $22.6 \%$ as moderate, and $49.9 \%$ as liberal.

\subsection{Measures}

Three survey scales comprised the central measures. Our belief in science, scale asked items such as, "How credible is the medical data that germs are a primary cause of disease?" and "How certain are you that physicists' theory of gravity accurately explains why objects fall when dropped?" The seven-item scale yielded reasonable internal consistency $(\alpha=.82)$. See Supplementary Materials for details on all scales.

Our seven-item belief in climate science scale $(\alpha=.97)$ paralleled the belief in science scale in form and tone. Through this scale, we assessed respondents' faith in a set of climate science findings. For instance, we asked, "How credible is the climate science data that ocean temperatures are rising?" and "How certain are you that global warming explains many of the new weather patterns we are seeing today?"

We adapted our egalitarianism scale from Kahan, Jekins-Smith, and Braman (2011). Our four-item scale $(\alpha=.87)$ assessed the degree to which participants valued greater societal equality and worried about inequality through items like, "How serious a problem is discrimination in the United States today?" Finally, participants indicated their political orientation by selecting one of 7 response options, extending from "very/somewhat/slightly liberal" to a midpoint of "moderate" to "slightly/somewhat/very conservative."

Across all scales — original and adapted — we employed current best practices in item wording and designing survey scales (Dillman, Smyth, \& Christian, 2014; Gehlbach, 2015; Gehlbach \& Artino, 2018). The main measures are listed in Appendix B.

\subsection{Procedures}

In early December 2017, we recruited Mechanical Turk “experts” and randomly assigned these participants to treatment or control. Treatment participants first completed the belief in science questions. Next, both conditions answered the belief in climate science items. In other words, the first survey scale served as an intervention to shift treatment respondents' beliefs on 
the second scale. From that point onward, all participants responded to all survey items in the same order. We paid respondents $\$ 2.00$ upon completion of the survey. The full list of variables collected can be found in our pre-registered Statement of Transparency (https://osf.io/pw4d2/).

\section{Results}

\subsection{Preliminary Analyses}

Several preliminary analyses set the stage for testing our pre-specified hypotheses. First, using multinomial logistic regression, we found no evidence of treatment-control disparities for gender, age, education, political orientation, or egalitarianism, $L R \chi^{2}(5)=3.12, p=.68$ due to randomization.

Next, a paired-sample $t$-test confirmed that our treatment respondents - particularly conservative participants - endorsed the belief in science items more than the belief in climate science items. Without this finding, our hypothesized consistency explanation would be implausible. This assumption held for treatment participants overall: belief in science scores $(M$ $=6.12, S D=0.74 ; 95 \% \mathrm{CI}: 6.04,6.20)$ versus belief in climate science scores $(M=5.29, S D=$ 1.48; 95\% CI: 5.14, 5.45), $t(340)=11.67, p<.001$; Cohen's $d=0.70$. A repeated-measures ANOVA showed larger discrepancies for conservative participants' belief in science scores relative to their belief in climate science scores $\left(M_{\text {diff }}=1.79 ; M s=6.02\right.$ and 4.23 , respectively $)$ as compared to their liberal counterparts within the treatment group $\left(M_{\text {diff }}=0.47 ; M s=6.15\right.$ and 5.68, respectively), $F(1)=49.18, p<.001$; Cohen's $d=0.57$.

Finally, a two-sample $t$-test on the full sample revealed no significant differences on the belief in science scores between conservatives $(M=6.02, S D=0.78 ; 95 \% \mathrm{CI}: 5.85,6.18)$ and their liberal and moderate peers $(M=6.15, S D=0.73,95 \% \mathrm{CI}: 6.06,6.24), t(337)=1.49, p=$ .14 ; Cohen's $d=0.18$.

\subsection{Hypothesis 1: Conservative Participants}

With these preliminary findings established, we tested our first pre-registered hypothesis that treatment participants would report greater belief in climate science than their control counterparts by fitting an OLS regression model with only our conservative participants. As 
predicted, conservative participants in the treatment group reported greater belief in climate science $(B=0.74, S E=0.24$; CI: 0.27, $1.20 ; p=.002$; Cohen's $d=.45$; see Figure $1 \mathrm{~A}$ and Appendix C).

We assessed the robustness of this finding by testing whether participants' political orientation moderated the effect of the treatment across the full sample by adding a Treatment $\mathrm{X}$ Political orientation interaction term to the model. This exploratory analysis showed that the intervention significantly bolstered belief in climate science for the overall sample $(B=0.26, S E$ $=0.12$; CI: $0.03,0.48, p=.026$; Cohen's $d=0.17$ ), but that the intervention was primarily effective for more conservative participants $(B=0.14, S E=0.05$; CI: $0.04,0.24, p=.005$; Cohen's $d=0.34)$. See Figures $1 \mathrm{~A}$ and $1 \mathrm{~B}$ and Appendix C.

Figure $1 \mathrm{~A}$ Belief in Climate Science

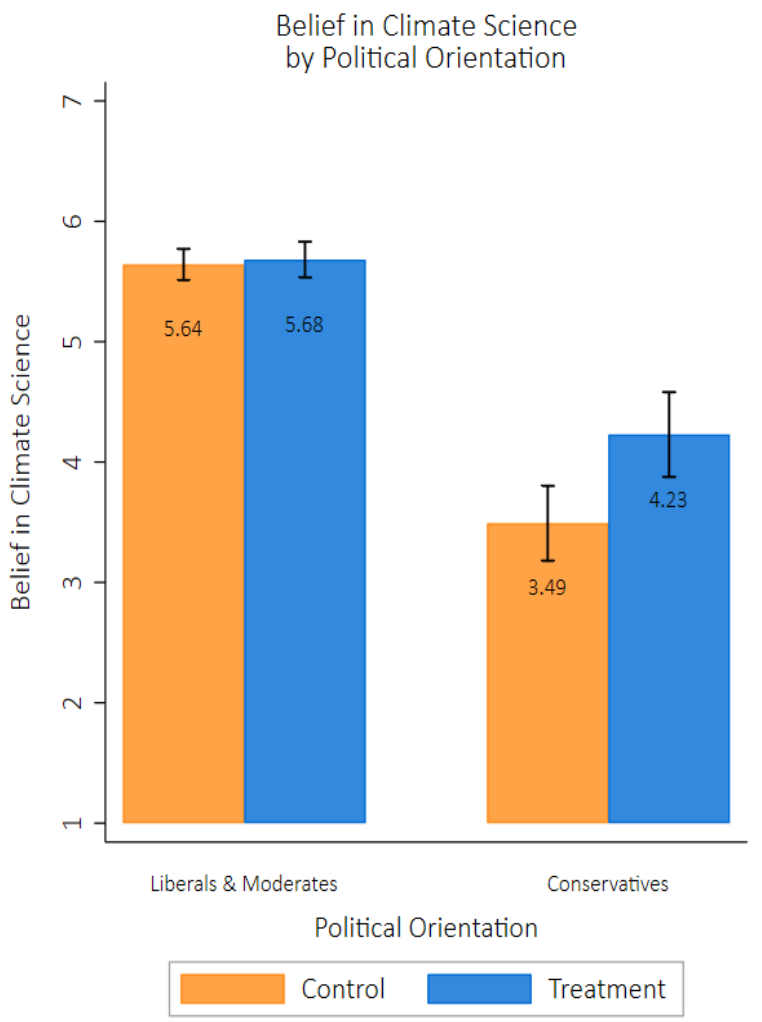

Figure 1B

Treatment x Political Orientation Interaction and Spotlight Analysis

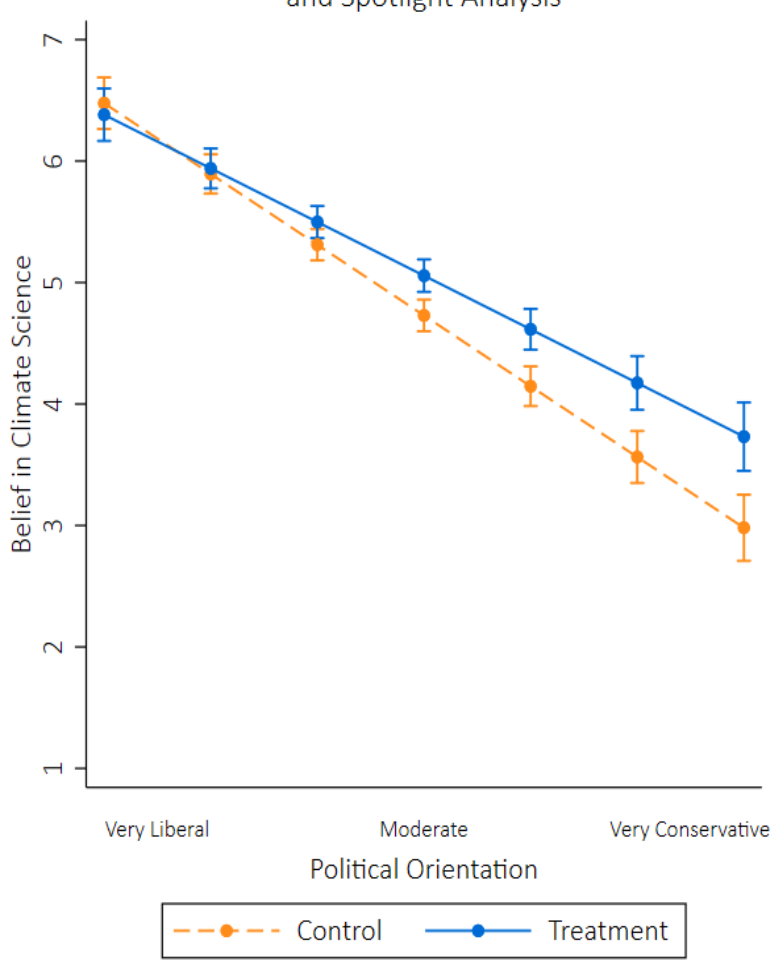

Figure $1 \mathrm{~A} \& 1 \mathrm{~B}$.

Differential effects of our intervention for moderates/liberals versus conservatives on the beliefs in climate science (with 95\% confidence intervals). 


\subsection{Hypothesis 2: Treatment x Egalitarianism}

Second, based on our exploratory study and Kahan's (2013) cultural cognition thesis, we hypothesized that the treatment would increase belief in climate science for participants with less egalitarian worldviews. Although this population overlaps with self-reported conservatives $(r(694)=-.64, p=.001)$, the shared variance is about $40 \%$, so the two groups are not identical. This hypothesis was not supported - results showed no evidence that the intervention was more effective for participants who held less egalitarian perspectives $(B=0.01, S E=0.09$; CI: -0.16 , $0.18, p=.911$; Cohen's $d=0.01)^{1}$

\section{Discussion}

Many Americans harbor doubts about climate change (Leiserowitz et al., 2018). Numerous climate skeptics presumably feel motivated to maintain social consistency with the groups they identify with-holding similar beliefs with others facilitates social harmony (Kahan, 2013; Montoya et al., 2008). This skepticism has impeded the United States' ability to address climate issues. To counter this societal pressure, we tested the efficacy of a cognitive consistency intervention. The intervention successfully shifted the attitudes of politically conservative participants, but did not significantly affect those with less egalitarian, more hierarchical worldviews.

Our results parallel past interventions that shifted climate skeptics' beliefs towards greater acceptance of climate change (e.g., Cook, Lewandowsky, \& Ecker, 2017). In addition, our findings support the notion that political orientation predicts climate change beliefs (McCright et al., 2013). Because this finding replicates our exploratory study, finds a large effect size relative to the duration of the intervention, and was pre-registered, we have additional confidence regarding this result.

By contrast, our second hypothesis did not replicate from our exploratory study and diverges from Kahan et al. (2012). Why might this finding fail to replicate? Perhaps the environmental focus of the belief in climate science items triggered the salience of participants'

\footnotetext{
${ }^{1}$ In line with Simmons, Nelson, and Simonsohn (2011), we also tested our pre-registered hypotheses (using the equations above) without eliminating any participants, i.e., we conducted an "intent-to-treat" analysis. Results remained essentially unchanged for the first $(B=0.70, S E=0.23 ; \mathrm{Cl}: 0.25,1.16 ; p=.003 ;$ Cohen's $d=.43)$ and second ( $B=-0.01, S E=0.08 ; \mathrm{Cl}:-0.17,0.16 ; p=.931 ;$ Cohen's $d=0.01$ ) hypotheses.
} 
(especially control participants') political identities (see Cohen, 2003) to a greater degree than their worldview. Meanwhile, conservatives in the treatment condition might have been partially inoculated against this priming of their political identity through the belief in science questions. These items seem unrelated to political orientation or worldview, and thus may have countered whatever social consistency motivation they might have felt. Alternatively, perhaps the relative importance of social consistency with one's political party has increased in the years since Kahan and colleagues conducted these studies making it a more powerful moderator in our analysis than in Kahan's analysis several years ago.

In line with Kahan and his colleagues (Kahan, 2013; Kahan et al., 2012), we posit that motivation for social consistency drives a substantial amount of climate skepticism. This approach then begs the question: With which social groups are climate skeptics trying to make their beliefs consistent? Our data suggest that political party affiliation is likely an important group.

On a practical note, although we are encouraged that such a brief intervention proved effective, these findings represent more of a proof-of-concept than a field experiment that demonstrates long-term changes in climate skeptics' attitudes. Nevertheless, our data show that believing in science might provide a promising common starting point for productively exploring different perspectives on climate challenges.

The promise of these findings should be balanced against several limitations and the need for additional studies. In addition to moving from a web-based convenience sample to a field experiment, better identifying which groups are most skeptical of climate science and which interventions might work best for them seems pivotal. Second, our intervention only leveraged one consistency motivation. Future field experiments might combine cognitive and social consistency motivations. Such interventions could build from Wolsko's (2017) idea that shared beliefs and building a common in-group identity may change people's environmental attitudes.

Currently in the U.S., few productive climate conversations span the political divide (Geiger \& Swim, 2016) despite the urgent need for such discussions. We hope others will further develop consistency strategies like the one used here to catalyze more productive conversations about climate change between parties with opposing perspectives but a common interest in preserving our planet. 


\section{REFERENCES}

Aronson, E. (1992). The return of the repressed: Dissonance theory makes a comeback. Psychological Inquiry, 3(4), 303-311.

Cialdini, R. B. (2009). Influence: Science and practice (5th ed.). Boston, MA: Pearson.

Cohen, G. L. (2003). Party over policy: The dominating impact of group influence on political beliefs. Journal of Personality and Social Psychology, 85(5), 808-822. doi:10.1037/0022-3514.85.5.808

Cook, J., Lewandowsky, S., \& Ecker, U. K. H. (2017). Neutralizing misinformation through inoculation: Exposing misleading argumentation techniques reduces their influence. PloS one, 12(5). doi:10.1371/journal.pone.0175799

Dillman, D. A., Smyth, J. D., \& Christian, L. M. (2014). Internet, phone, mail, and mixed-mode surveys: The tailored design method (4th ed.). Hoboken, NJ: John Wiley \& Sons.

Festinger, L. (1962). Cognitive dissonance. Scientific American, 207(4), 93-107.

Gauchat, G. (2012). Politicization of science in the public sphere: A study of public trust in the United States, 1974 to 2010. American Sociological Review, 77(2), 167-187. doi:http://dx.doi.org/10.1177/0003122412438225

Gehlbach, H. (2015). Seven survey sins. The Journal of Early Adolescence, 35, 883-897. doi:10.1177/0272431615578276

Gehlbach, H., \& Artino, A. R. (2018). The survey checklist (manifesto). Academic Medicine: Journal Of The Association Of American Medical Colleges, 93(3), 360-366. doi:10.1097/ACM.0000000000002083

Gehlbach, H., \& Robinson, C. D. (2018). Mitigating illusory results through preregistration in education. Journal of Research on Educational Effectiveness, 11(2), 296-315. doi:10.1080/19345747.2017.1387950

Gehlbach, H., Robinson, C. D., Finefter-Rosenbluh, I., Benshoof, C., \& Schneider, J. (2018). Questionnaires as interventions: Can taking a survey increase teachers' openness to student feedback surveys? Educational Psychology, 38(3), 350-367. doi:10.1080/01443410.2017.1349876

Geiger, N., \& Swim, J. K. (2016). Climate of silence: Pluralistic ignorance as a barrier to climate change discussion. Journal of Environmental Psychology, 47, 79-90. doi:https://doi.org/10.1016/i.jenvp.2016.05.002

Kahan, D. M. (2013). Ideology, motivated reasoning, and cognitive reflection. Judgment and Decision Making, 8(4), 407-424.

Kahan, D. M. (2015). Climate-science communication and the measurement problem. Political Psychology, 36(s1), 1-43. doi:http://dx.doi.org/10.1111/pops.12244

Kahan, D. M., Jenkins-Smith, H., \& Braman, D. (2011). Cultural cognition of scientific consensus. Journal of Risk Research, 14(2), 147-174. doi:http://dx.doi.org/10.1080/13669877.2010.511246

Kahan, D. M., Peters, E., Wittlin, M., Slovic, P., Ouellette, L. L., Braman, D., \& Mandel, G. (2012). The polarizing impact of science literacy and numeracy on perceived climate change risks. Nature Climate Change, 2(10), 732-735. doi:http://dx.doi.org/10.1038/nclimate1547

Leiserowitz, A., Maibach, E., Roser-Renouf, C., Rosenthal, S., Cutler, M., \& Kotcher, J. (2018). Climate change in the American mind: March 2018. Retrieved from New Haven, CT: Yale Program on Climate Change Communication: http://climatecommunication.yale.edu/publications/climate-change-american-mindmarch-2018/ 


\section{LEVERAGING COGNITIVE CONSISTENCY}

McCright, A. M., Dunlap, R. E., \& Xiao, C. (2013). Perceived scientific agreement and support for government action on climate change in the USA. Climatic Change, 119(2), 511-518. doi:10.1007/s10584-013-0704-9

Montoya, R. M., Horton, R. S., \& Kirchner, J. (2008). Is actual similarity necessary for attraction? A meta-analysis of actual and perceived similarity. Journal of Social and Personal Relationships, 25(6), 889-922. doi: $10.1177 / 0265407508096700$

Oreskes, N., \& Conway, E. M. (2010). Merchants of doubt: How a handful of scientists obscured the truth on issues from tobacco smoke to global warming (1st U.S. ed.). New York: Bloomsbury Press.

Piaget, J. (1977). Problems of equilibration. In M. H. Appel \& L. S. Goldberg (Eds.), Topics in Cognitive Development: Equilibration: Theory, Research, and Application (pp. 3-13). Boston, MA: Springer US.

Simmons, J. P., Nelson, L. D., \& Simonsohn, U. (2011). False-positive psychology: Undisclosed flexibility in data collection and analysis allows presenting anything as significant. Psychological Science, 22(11), 13591366. doi:10.1177/0956797611417632

Spiller, S. A., Fitzsimons, G. J., Lynch, J. G., Jr., \& McClelland, G. H. (2013). Spotlights, floodlights, and the magic number zero: Simple effects tests in moderated regression. Journal of Marketing Research, 50(2), 277-288. doi:http://dx.doi.org/10.1509/jmr.12.0420

Wolsko, C. (2017). Expanding the range of environmental values: Political orientation, moral foundations, and the common ingroup. Journal of Environmental Psychology, 51, 284-294. doi:https://doi.org/10.1016/j.jenvp.2017.04.005 


\section{Supplementary Online Materials}

\section{Appendix A: Exploratory Study}

This study closely mirrors the main study with the exception that it was exploratory-that is, we did not pre-register any specific hypotheses (Gehlbach \& Robinson, 2018). For the sake of full transparency, we present the methods and results of this initial study. The main points we strive to establish are that (1) there was an empirical basis for our decision to hypothesize that egalitarianism would moderate the effects of the intervention on participants' beliefs in climate science, and (2) our main finding that political orientation moderates the effect of the intervention is a replicated finding.

\section{Methods}

Participants. In this preliminary study, 634 participants entered the survey and ultimately yielded an analytic sample of $N=472$. We excluded participants prior to condition assignment because (a) they had taken one of our previous surveys on the environment $(n=32)$, or (b) they failed the initial attention check $(n=59)$. After randomization occurred, (c) an additional 30 participants did not complete the belief in climate science scale and thus were not included in most analyses. Next, using Barge and Gehlbach's (2012) approach, (d) we removed 22 participants who gave identical sequential responses (e.g., consistently answering with the fourth response option) on the seven belief in climate science items and our "trap" item. Finally, (e) we also removed an additional 19 participants who answered the belief in climate science items in less than 40 seconds.

Of these final 472 participants ( $n=243$ control condition; $n=229$ treatment condition), our sample was $49.6 \%$ female (10 participants did not disclose their gender) and had a mean age of 39.8 years old $(S D=11.8)$; the median participant held a four-year college degree. Politically, $27.1 \%$ of the participants self-reported being conservative-leaning, $19.9 \%$ as moderate, and $51.7 \%$ as liberal-leaning (overall $M=-0.58, S D=1.85$ on a seven-point array of response options that ranged from "very liberal" to "very conservative"; 6 participants did not report their political orientation).

Measures. The core survey scales that comprised our central measures were identical between our exploratory and pre-registered studies. Like our main study, the psychometric properties of each scale in our exploratory study were reasonable: belief in science $(\alpha=.78$; 
eigenvalue of 3.02 with $43 \%$ of the variance explained), belief in climate science $(\alpha=.97$; eigenvalue of 5.84 with $83 \%$ of the variance explained), and egalitarianism ( $\alpha=.90$; eigenvalue of 3.06 with $76 \%$ of the variance explained)

Procedures. We opened data collection for this study on Mechanical Turk on October 31, 2017 and concluded on November 8, 2017. We recruited participants who were considered “Experts" based on prior quality ratings by Mechanical Turk and paid them $\$ 2.00$ to complete the task.

\section{Results}

First, we checked to ensure that randomization worked for our treatment and control groups. We found a slight age imbalance - participants assigned to the treatment condition were an average of 2.3 years older than control participants, $t(464)=2.1, p=.037$. No other evidence of group differences emerged on those key characteristics that we could measure: gender, education, political orientation, or egalitarianism. A multinomial logistic regression predicting condition assignment with available covariates for all participants was not statistically significant, $L R \chi^{2}(4)=6.19, p=.27$, suggesting the difference in age between the conditions was largely a function of testing multiple demographic characteristics.

For our manipulation to work, we needed participants - particularly conservative participants - to endorse the belief in science items more readily than the belief in climate science items. We found that this assumption held. Conservative participants' belief in science scores $(M=6.02, S D=0.68,95 \%$ CI: $5.85,6.19)$ were substantially higher than their belief in climate science scores $(M=4.06, S D=1.61,95 \% \mathrm{CI}: 3.66,4.47), t(63)=10.5, p<.001$; Cohen's $d=1.60$.

In addition, because we aspired to find common ground between conservatives and their more moderate and liberal peers, we needed to establish that any between-group differences on participants' belief in science scores were modest. This assumption appeared to be reasonable: conservatives' belief in science scores $(M=6.02, S D=0.68,95 \% \mathrm{CI}: 5.85,6.19)$ were not statistically significantly different than their liberal and moderate peers $(M=6.2, S D=0.68,95 \%$ CI: 6.1, 6.31), $t(224)=1.8, p=.073$; Cohen's $d=0.27$.

With these prerequisites established, we turned to our primary analyses of interest. Our main findings suggest that our manipulation of having treatment participants report on a belief in 
science scale prior to completing our belief in climate science scale effectively shifts the views of our conservative participants. In looking only at conservatives, our treatment participants reported believing in climate science more than their control counterparts $(B=0.84, S E=0.30$; CI: $0.25,1.44 ; t(126)=2.82, p=.006$; Cohen's $d=0.50){ }^{2}$

To further explore this finding we conducted two additional tests. First, using an interaction term (consisting of our 7-point political orientation scale and the treatment) and our full sample, we found that the effects of the intervention appeared stronger for participants who were more right-leaning in their political orientation $(B=0.18, S E=0.06$, CI: $0.06,0.30 ; p=$ .003 , Cohen's $d=0.43$ ). Second, based on the notion that certain cultural orientations might more precisely distinguish people's divergent views on climate change (Kahan et al., 2011), we tested whether the treatment disproportionately affected those who were low on egalitarianism (i.e., by interacting participants' scores on the egalitarianism scale with our treatment). We found that the intervention was more effective for participants with less egalitarian perspectives $(B=-0.27, S E=0.10 ; 95 \%$ CI: $-0.46,-0.08, p=.006$; Cohen's $d=-0.39)$. These findings and the guidelines of Gehlbach and Robinson (2018) guided our pre-registration decisions for the main study.

\footnotetext{
${ }^{2}$ Controlling for age produces similar results: $B=0.91, S E=0.29$, CI: $0.33,1.49 ; t(125)=3.1, p=.002$; Cohen's $d$ $=0.54$.
} 


\section{Appendix B: Methods}

\section{Measures}

Key Measure 1: Belief in Science ( $\alpha=.82$; the principal component had an eigenvalue of 3.36 and explained $48 \%$ of the variance).

Scientific advances directly affect our own lives in many ways. For example, contributions from mechanical engineering improve the quality and safety of new cars every year. Thanks to advances in computer science, computers, tablets, and smart phones get faster, sharper, and more capable almost continuously.

\section{In short, science informs our lives in many ways. However, people differ in their opinions about the contributions of different branches of science.}

\section{Instructions: Please give us your opinions and thoughts about the contributions of different branches of science.}

\begin{tabular}{|c|c|c|c|c|c|c|c|}
\hline $\begin{array}{l}\text { To what degree do you think the science of } \\
\text { astronomy has helped us identify what other } \\
\text { planets exist in our solar system? }\end{array}$ & $\begin{array}{l}\text { Not } \\
\text { at all }\end{array}$ & $\begin{array}{l}\text { A very little } \\
\text { bit }\end{array}$ & $\begin{array}{l}\text { A modest } \\
\text { amount }\end{array}$ & Somewhat & $\begin{array}{l}\text { Quite } \\
\text { a bit }\end{array}$ & $\begin{array}{l}\text { Very } \\
\text { much }\end{array}$ & $\begin{array}{l}\text { A tremendous } \\
\text { amount }\end{array}$ \\
\hline $\begin{array}{l}\text { How helpful do you think medical science is in } \\
\text { advancing society's understanding of what } \\
\text { makes people sick? }\end{array}$ & $\begin{array}{l}\text { Not helpful at } \\
\text { all }\end{array}$ & $\begin{array}{l}\text { A tiny bit } \\
\text { helpful }\end{array}$ & $\begin{array}{l}\text { A little } \\
\text { helpful }\end{array}$ & $\begin{array}{l}\text { Somewhat } \\
\text { helpful }\end{array}$ & $\begin{array}{l}\text { Quite } \\
\text { helpful }\end{array}$ & $\begin{array}{l}\text { Very } \\
\text { helpful }\end{array}$ & $\begin{array}{l}\text { Extremely } \\
\text { helpful }\end{array}$ \\
\hline $\begin{array}{l}\text { How confident are you that the field of } \\
\text { engineering is advanced enough to keep you } \\
\text { safe when traveling on bridges? }\end{array}$ & $\begin{array}{l}\text { Not at all } \\
\text { confident }\end{array}$ & $\begin{array}{l}\text { A tiny bit } \\
\text { confident }\end{array}$ & $\begin{array}{l}\text { A little } \\
\text { confident }\end{array}$ & $\begin{array}{l}\text { Somewhat } \\
\text { confident }\end{array}$ & $\begin{array}{l}\text { Quite } \\
\text { confident }\end{array}$ & $\begin{array}{l}\text { Very } \\
\text { confident }\end{array}$ & $\begin{array}{l}\text { Extremely } \\
\text { confident }\end{array}$ \\
\hline $\begin{array}{l}\text { How certain are you that physicists' theory of } \\
\text { gravity accurately explains why objects fall } \\
\text { when dropped? }\end{array}$ & $\begin{array}{l}\text { Not certain at } \\
\text { all }\end{array}$ & $\begin{array}{l}\text { A tiny bit } \\
\text { certain }\end{array}$ & $\begin{array}{l}\text { A little } \\
\text { certain }\end{array}$ & $\begin{array}{l}\text { Somewhat } \\
\text { certain }\end{array}$ & Quite certain & $\begin{array}{l}\text { Very } \\
\text { certain }\end{array}$ & $\begin{array}{l}\text { Extremely } \\
\text { certain }\end{array}$ \\
\hline $\begin{array}{l}\text { How useful is neuroscience in helping } \\
\text { understand the role of different areas of the } \\
\text { brain? }\end{array}$ & $\begin{array}{l}\text { Not useful at } \\
\text { all }\end{array}$ & $\begin{array}{l}\text { A tiny bit } \\
\text { useful }\end{array}$ & $\begin{array}{l}\text { A little } \\
\text { useful }\end{array}$ & $\begin{array}{l}\text { Somewhat } \\
\text { useful }\end{array}$ & Quite useful & $\begin{array}{l}\text { Very } \\
\text { useful }\end{array}$ & $\begin{array}{l}\text { Extremely } \\
\text { useful }\end{array}$ \\
\hline $\begin{array}{l}\text { To what degree do you agree with public health } \\
\text { experts that smoking causes cancer? }\end{array}$ & $\begin{array}{l}\text { Not } \\
\text { at all }\end{array}$ & $\begin{array}{l}\text { A very little } \\
\text { bit }\end{array}$ & $\begin{array}{l}\text { A modest } \\
\text { amount }\end{array}$ & Somewhat & $\begin{array}{l}\text { Quite } \\
\text { a bit }\end{array}$ & $\begin{array}{l}\text { Very } \\
\text { much }\end{array}$ & $\begin{array}{l}\text { A tremendous } \\
\text { amount }\end{array}$ \\
\hline $\begin{array}{l}\text { How credible is the medical data that germs are } \\
\text { a primary cause of disease? }\end{array}$ & $\begin{array}{l}\text { Not credible at } \\
\text { all }\end{array}$ & $\begin{array}{l}\text { A tiny bit } \\
\text { credible }\end{array}$ & $\begin{array}{l}\text { A little } \\
\text { credible }\end{array}$ & $\begin{array}{l}\text { Somewhat } \\
\text { credible }\end{array}$ & $\begin{array}{l}\text { Quite } \\
\text { credible }\end{array}$ & $\begin{array}{l}\text { Very } \\
\text { credible }\end{array}$ & $\begin{array}{l}\text { Completely } \\
\text { credible }\end{array}$ \\
\hline
\end{tabular}




\section{LEVERAGING COGNITIVE CONSISTENCY}

Key Measure 2: Beliefs in Climate Science ( $\alpha=.97$; the principal component had an eigenvalue of 5.80 and explained $83 \%$ of the variance).

\section{Instructions: Please give us your opinions regarding different aspects of what scientists have concluded about climate change and global warming.}

\begin{tabular}{|c|c|c|c|c|c|c|c|}
\hline $\begin{array}{l}\text { With how much precision has the science of } \\
\text { climate change been able to identify the } \\
\text { causes behind rising sea levels? }\end{array}$ & $\begin{array}{l}\text { With no } \\
\text { precision } \\
\text { at all }\end{array}$ & $\begin{array}{l}\text { With a very } \\
\text { little bit of } \\
\text { precision }\end{array}$ & $\begin{array}{l}\text { With a } \\
\text { modest } \\
\text { amount of } \\
\text { precision }\end{array}$ & $\begin{array}{l}\text { With some } \\
\text { precision }\end{array}$ & $\begin{array}{l}\text { With quite a } \\
\text { bit of } \\
\text { precision }\end{array}$ & $\begin{array}{l}\text { With a great } \\
\text { deal of } \\
\text { precision }\end{array}$ & $\begin{array}{l}\text { With perfect } \\
\text { precision }\end{array}$ \\
\hline $\begin{array}{l}\text { How helpful do you think climate science is } \\
\text { in advancing society's understanding of why } \\
\text { the earth is getting hotter? }\end{array}$ & $\begin{array}{l}\text { Not helpful at } \\
\text { all }\end{array}$ & $\begin{array}{l}\text { A tiny bit } \\
\text { helpful }\end{array}$ & $\begin{array}{l}\text { A little } \\
\text { helpful }\end{array}$ & $\begin{array}{l}\text { Somewhat } \\
\text { helpful }\end{array}$ & $\begin{array}{l}\text { Quite } \\
\text { helpful }\end{array}$ & $\begin{array}{l}\text { Very } \\
\text { helpful }\end{array}$ & $\begin{array}{l}\text { Extremely } \\
\text { helpful }\end{array}$ \\
\hline $\begin{array}{l}\text { How confident are you that climate science is } \\
\text { right in their theory of how greenhouse gases } \\
\text { trap heat? }\end{array}$ & $\begin{array}{l}\text { Not at all } \\
\text { confident }\end{array}$ & $\begin{array}{l}\text { A tiny bit } \\
\text { confident }\end{array}$ & $\begin{array}{l}\text { A little } \\
\text { confident }\end{array}$ & $\begin{array}{l}\text { Somewhat } \\
\text { confident }\end{array}$ & $\begin{array}{l}\text { Quite } \\
\text { confident }\end{array}$ & Very confident & $\begin{array}{l}\text { Extremely } \\
\text { confident }\end{array}$ \\
\hline $\begin{array}{l}\text { How certain are you that global warming } \\
\text { explains many of the new weather patterns } \\
\text { we are seeing today? }\end{array}$ & $\begin{array}{l}\text { Not certain at } \\
\text { all }\end{array}$ & $\begin{array}{l}\text { A tiny bit } \\
\text { certain }\end{array}$ & $\begin{array}{l}\text { A little } \\
\text { certain }\end{array}$ & $\begin{array}{l}\text { Somewhat } \\
\text { certain }\end{array}$ & Quite certain & $\begin{array}{l}\text { Very } \\
\text { certain }\end{array}$ & $\begin{array}{l}\text { Extremely } \\
\text { certain }\end{array}$ \\
\hline $\begin{array}{l}\text { How useful are climate models in helping to } \\
\text { predict how many species are likely to go } \\
\text { extinct in the coming years? }\end{array}$ & $\begin{array}{l}\text { Not useful at } \\
\text { all }\end{array}$ & $\begin{array}{l}\text { A tiny bit } \\
\text { useful }\end{array}$ & $\begin{array}{l}\text { A little } \\
\text { useful }\end{array}$ & $\begin{array}{l}\text { Somewhat } \\
\text { useful }\end{array}$ & Quite useful & $\begin{array}{l}\text { Very } \\
\text { useful }\end{array}$ & $\begin{array}{l}\text { Extremely } \\
\text { useful }\end{array}$ \\
\hline $\begin{array}{l}\text { To what extent do you agree with climate } \\
\text { experts that humans burning fossil fuels is } \\
\text { the major cause of our changing climate? }\end{array}$ & $\begin{array}{l}\text { Not } \\
\text { at all }\end{array}$ & $\begin{array}{l}\text { A very little } \\
\text { bit }\end{array}$ & $\begin{array}{l}\text { A modest } \\
\text { amount }\end{array}$ & Somewhat & $\begin{array}{l}\text { Quite } \\
\text { a bit }\end{array}$ & $\begin{array}{l}\text { Very } \\
\text { much }\end{array}$ & $\begin{array}{l}\text { A tremendous } \\
\text { amount }\end{array}$ \\
\hline $\begin{array}{l}* * \text { How accurately do you think climate } \\
\text { scientists will predict the exact number of } \\
\text { degrees the average global temperature will } \\
\text { change between now and the year } 2050 ? * *\end{array}$ & $\begin{array}{l}\text { Not accurately } \\
\text { at all }\end{array}$ & $\begin{array}{l}\text { A tiny bit } \\
\text { accurately }\end{array}$ & $\begin{array}{l}\text { A little } \\
\text { accurately }\end{array}$ & $\begin{array}{l}\text { Somewhat } \\
\text { accurately }\end{array}$ & $\begin{array}{l}\text { Quite } \\
\text { accurately }\end{array}$ & $\begin{array}{l}\text { Very } \\
\text { accurately }\end{array}$ & $\begin{array}{l}\text { Extremely } \\
\text { accurately }\end{array}$ \\
\hline $\begin{array}{l}\text { How credible is the climate science data that } \\
\text { ocean temperatures are rising? }\end{array}$ & $\begin{array}{l}\text { Not credible at } \\
\text { all }\end{array}$ & $\begin{array}{l}\text { A tiny bit } \\
\text { credible }\end{array}$ & $\begin{array}{l}\text { A little } \\
\text { credible }\end{array}$ & $\begin{array}{l}\text { Somewhat } \\
\text { credible }\end{array}$ & $\begin{array}{l}\text { Quite } \\
\text { credible }\end{array}$ & Very credible & $\begin{array}{l}\text { Completely } \\
\text { credible }\end{array}$ \\
\hline
\end{tabular}




\section{LEVERAGING COGNITIVE CONSISTENCY}

Key Measure 3: Egalitarianism ( $\alpha=.87$; the principal component had an eigenvalue of 2.88 and explained $72 \%$ of the variance).

Instructions: In this section, we are now interested in getting a sense of some of your attitudes towards society more generally.

\begin{tabular}{|c|c|c|c|c|c|}
\hline $\begin{array}{l}\text { How much better off would our society be if the distribution of wealth } \\
\text { were more equal? }\end{array}$ & $\begin{array}{l}\text { No } \\
\text { better off }\end{array}$ & $\begin{array}{l}\text { Slightly better } \\
\text { off }\end{array}$ & $\begin{array}{l}\text { Somewhat } \\
\text { better off }\end{array}$ & $\begin{array}{l}\text { Quite a bit } \\
\text { better off }\end{array}$ & $\begin{array}{l}\text { Tremendously } \\
\text { better off }\end{array}$ \\
\hline How serious a problem is discrimination in the United States today? & $\begin{array}{l}\text { Not at all } \\
\text { serious }\end{array}$ & $\begin{array}{l}\text { Slightly } \\
\text { serious }\end{array}$ & $\begin{array}{l}\text { Somewhat } \\
\text { serious }\end{array}$ & $\begin{array}{l}\text { Quite } \\
\text { serious }\end{array}$ & Extremely serious \\
\hline $\begin{array}{l}\text { Over the next few years, how much of a priority is it for the government to } \\
\text { make more progress on equal rights for all citizens? }\end{array}$ & $\begin{array}{l}\text { Not a priority at } \\
\text { all }\end{array}$ & A low priority & $\begin{array}{l}\text { A moderate } \\
\text { priority }\end{array}$ & $\begin{array}{l}\text { A pretty } \\
\text { high priority }\end{array}$ & $\begin{array}{l}\text { A top } \\
\text { priority }\end{array}$ \\
\hline $\begin{array}{l}\text { For the well-being of our country, how important is it to reduce } \\
\text { inequalities? }\end{array}$ & $\begin{array}{l}\text { Not at all } \\
\text { important }\end{array}$ & $\begin{array}{l}\text { Slightly } \\
\text { important }\end{array}$ & $\begin{array}{l}\text { Somewhat } \\
\text { important }\end{array}$ & $\begin{array}{l}\text { Quite } \\
\text { important }\end{array}$ & $\begin{array}{l}\text { Extremely } \\
\text { important }\end{array}$ \\
\hline
\end{tabular}

Key Demographic Variable: Political Orientation

\section{Demographic Item}

\begin{tabular}{|c|c|c|c|c|c|c|c|}
\hline $\begin{array}{l}\text { Generally speaking, how would you describe } \\
\text { your political orientation? }\end{array}$ & $\begin{array}{l}\text { Very } \\
\text { liberal }\end{array}$ & $\begin{array}{l}\text { Somewhat } \\
\text { liberal }\end{array}$ & $\begin{array}{l}\text { Slightly } \\
\text { liberal }\end{array}$ & Moderate & $\begin{array}{l}\text { Slightly } \\
\text { conservative }\end{array}$ & $\begin{array}{l}\text { Somewhat } \\
\text { conservative }\end{array}$ & $\begin{array}{l}\text { Very } \\
\text { conservative }\end{array}$ \\
\hline
\end{tabular}




\section{Sample attrition:}

Attrition and exclusion unfolded as follows: (a) 2 participants did not consent to participating, (b) we excluded 64 participants who had taken the exploratory study, and (c) 74 participants failed an initial attention check. After the remaining participants were randomly assigned to treatment and control conditions, (d) 13 participants did not complete the belief in climate science scale and thus were not included in most analyses.

Congruent with our pre-specified plan and exploratory study's procedure, we used a "trap" item - "How accurately do you think climate scientists will predict the exact number of degrees the average global temperature will change between now and the year 2050?"between two types of "straight-lining" participants. (e) We excluded the 39 climate-change believing straight-liners who gave identical sequential responses on all belief in climate science items and the "trap" item on the grounds that they could not reasonably endorse the trap item as strongly as the other items. We retained the 11 climate skeptics who straight-lined because their low endorsements of the climate science and trap item could easily represent veridical beliefs. Finally, (f) we removed an additional 15 participants who sped through the belief in climate science items in under 40 seconds - an implausibly fast time based on our pilot testing.

The rates of attrition and exclusion were comparable across both groups given that the treatment group had to complete an additional scale and would thus be more likely to drop out (given the appearance of a slightly more time-intensive initial task). In line with the procedures stated in our pre-registration plan, we excluded 25 control participants $(6.5 \%)$ and 42 treatment participants $(11 \%), \chi^{2}(1)=4.73, p=.03$ after random assignment occurred. 


\section{Appendix C: Supplementary Data Tables and Figures}

Table S1:

Full regression models for the effect of the treatment on participants' belief in climate science.

Belief in Climate Science (Unstandardized)

Variables

(1)

(2)

(3)

(4)

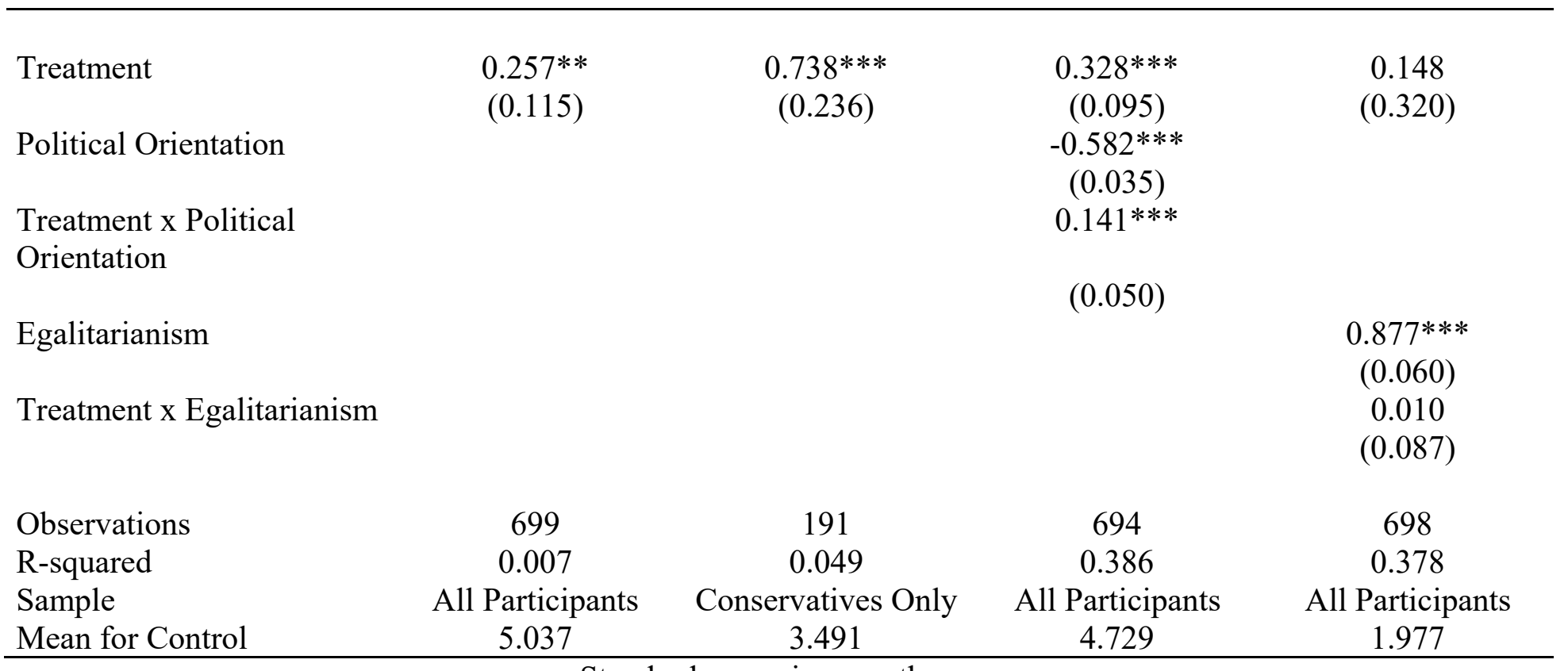

Standard errors in parentheses *** $\mathrm{p}<0.01, * * \mathrm{p}<0.05, * \mathrm{p}<0.1$ 


\section{Table S2:}

Regression model for the nonlinear interaction between treatment $x$ political orientation on participants' belief in climate science.

Belief in Climate Science

Variables

\begin{tabular}{lc}
\hline & \\
Treatment & $0.318^{* *}$ \\
& $(0.131)$ \\
Political Orientation & $-0.613^{* * *}$ \\
& $(0.036)$ \\
Treatment x Political Orientation & $0.121^{* *}$ \\
& $(0.052)$ \\
Political Orientation x Political Orientation & $-0.071^{* * *}$ \\
& $(0.020)$ \\
Treatment x Political Orientation x Political Orientation & -0.001 \\
& $(0.028)$ \\
Observations & 694 \\
R-squared & 0.408 \\
Sample & All Participants \\
\hline
\end{tabular}

$$
\begin{aligned}
& \text { Standard errors in parentheses } \\
& * * * \mathrm{p}<0.01, * * \mathrm{p}<0.05, * \mathrm{p}<0.1
\end{aligned}
$$


Figure S1:

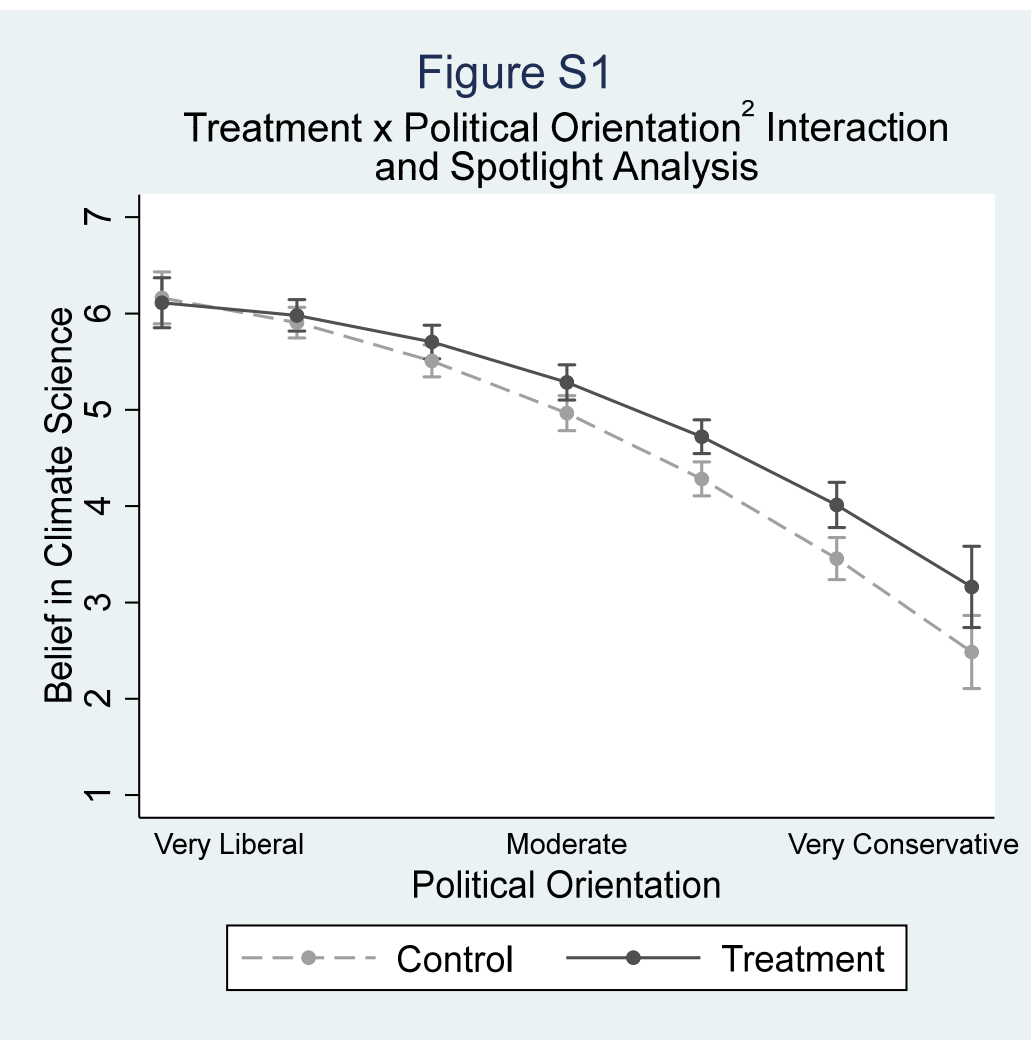

A spotlight analysis (Spiller, Fitzsimons, Lynch, \& McClelland, 2013)—with 95\% confidence intervals-examining each possible political orientation shows that the treatment had a small effect on politically moderate participants' climate science beliefs; the impact was larger for more conservative participants. 